\title{
Costs of provision for in-home care services for dependent persons in selected Polish cities 2015-2017. Challenges for local governments
}

\author{
Koszty świadczenia usług opiekuńczych dla osób zależnych w miejscu \\ zamieszkania w Polsce w latach 2015-2017. Wyzwania dla samorządów
}

\author{
Marta Giezek ${ }^{1, A-D, F}{ }^{\infty}$, Paulina Zabielska ${ }^{1, B, E} \oplus$, Beata Karakiewicz ${ }^{1, E-F} \oplus$ \\ ${ }^{1}$ Subdepartment of Social Medicine and Public Health, Department of Social Medicine, Pomeranian Medical University in \\ Szczecin, Poland \\ A - Research concept and design, B - Collection and/or assembly of data, C - Data analysis and interpretation, \\ $D$ - Writing the article, E-Critical revision of the article, F- Final approval of article
}

Giezek M, Zabielska P, Karakiewicz B. Costs of provision for in-home care services for dependent persons in selected Polish cities $2015-2017$. Challenges for local governments. Med Og Nauk Zdr. 2020; 26(2): 164-168. doi: 10.26444/monz/119166

\begin{abstract}
Introduction and objective. The provision of safety and professional care for dependent persons, including the elderly and the disabled at home, is one of the biggest challenges for health policy and social assistance. The aim of the study is to analyse the costs of care services in Poland in 2015-2017, and to identify future needs.

Materials and method. In the research process, material from 12 out of 27 randomly-selected Polish cities with over 120,000 inhabitants was analysed in terms of the form of care services provided, i.e. care services, specialist care services as municipalities' own tasks, and financed from the municipal budget, and specialist care services for persons with mental disorders-commissioned tasks financed from the State budget. Results. UOs (also called housekeeping services), are the most frequently granted form of assistance, and are most often used by persons over 80 years of age. SUOP are mainly provided to young people. In the majority of the cities in the study, the cost of care services increased every year, with the largest increase recorded in 2017.

Conclusions. It was concluded that care services are the fundamental and least costly form of care for elderly persons at home. Despite this, growing demand in this area necessitates increased annual budgets of Polish municipalities for this purpose. The lack of nationwide standards for the provision of care services prevents specification of a detailed array of activities to be performed by carers for the environment of elderly persons. Although an increased minimum salary has a significant impact on the costs of services, their hourly settlement hinders assessment of their quality. The greater the involvement of informal carers, the lower the costs for local governments.
\end{abstract}

\section{Key words}

care services, social assistance, dependent persons

\footnotetext{
Address for correspondence: Paulina Zabielska, Subdepartment of Social Medicine and Public Health, Department of Social Medicine, Pomeranian Medical University in Szczecin, Poland

E-mail: paulina.zabielska@pum.edu.pl

Received: 04.02.2020; accepted: 18.03.2020; first published: 20.04.2020
}

\section{Streszczenie}

Cel pracy. Zapewnienie bezpieczeństwa i profesjonalnej opieki osobom zależnym, w tym starszym i niepełnosprawnym, w ich miejscu zamieszkania jest bez wątpienia jednym z największych wyzwań dla polityki zdrowotnej i pomocy społecznej. Celem pracy była analiza kosztów realizacji usług opiekuńczych Polsce w latach 2015-2017 oraz na tej podstawie wskazanie potrzeb w tym zakresie w najbliższej perspektywie czasowej.

Materiał i metody. W procesie badawczym materiał z 12 miast w Polsce poddano analizie pod względem formy świadczonych usług opiekuńczych, tj.: usługi opiekuńcze i specjalistyczne usługi opiekuńcze jako zadania własne - finansowane z budżetu gminy oraz specjalistyczne usługi opiekuńcze dla osób z zaburzeniami psychicznymi - zadanie zlecone finansowane z budżetu państwa.

Wyniki. Usługi opiekuńcze (UO), nazywane również usługami gospodarczymi, są najczęściej przyznawaną formą pomocy, a korzystają z nich najczęściej osoby powyżej 80. roku życia. SUOP dedykowane są głównie osobom młodym. W większości badanych miast koszty ponoszone na świadczone usługi opiekuńcze wzrastały każdego roku, jednak największe podwyżki odnotowano w roku 2017.

Wnioski. Usługi opiekuńcze są podstawową i najmniej kosztowną formą opieki nad osobą starszą w jej miejscu zamieszkania. Mimo to rosnące $w$ tym zakresie zapotrzebowanie powoduje konieczność corocznego zwiększania budżetów gmin na to zadanie. Brak wprowadzenia ogólnopolskich standardów w zakresie świadczenia usług opiekuńczych skutkuje tym, iż nie sporządzono szczegółowego katalogu czynności przewidzianych do wykonania w ramach pracy opiekuna w środowisku osoby starszej. Wzrost płacy minimalnej ma istotne przełożenie na koszty świadczonych usług, jednak godzinowe ich rozliczanie utrudnia faktyczną ocenę jakości ich świadczenia.

\section{Słowa kluczowe}

usługi opiekuńcze, pomoc społeczna, osoby zależne 


\section{INTRODUCTION}

Ensuring safety and professional care for dependent people, including the elderly and the disabled at home, is undoubtedly one of the biggest challenges for health policy and social assistance. The aim of this care is not so much striving to recover former vitality and health by the elderly, but to achieve improvement of their quality of life through support, care and nursing, while maintaining their dignity and self-determination. In elderly persons, the need for care is associated with the phenomenon of changes in proportions, characteristic of old age - life experience and wisdom increase, whereas physical and mental fitness decrease, which is an expression of aging [1]. It is expected that by the end of 2050 the number of people over the age of 65 will increase by 19 percentage points in Polish cities, and slightly less (16.8 pp) in the countryside. The proportion of elderly people will exceed $30 \%$ in rural areas and will approach $35 \%$ in urban areas. On a national scale, this population will increase by 5.4 million [2]. It is estimated that the percentage of persons aged 65-69 who require the assistance of other people is $5.5 \%$, while this figure increases to $50.3 \%$ for persons aged 90 and over [3].

Care provision for dependent elderly and disabled people is associated with specific costs incurred by families or municipalities [4]. The most beneficial form of care for elderly persons, both in psychosocial and economic terms, is to provide them with the opportunity to function in their home environment for as long as possible. For this purpose, care services (usługi opiekuńcze - UO) and specialist care services (specjalistyczne usługi opiekuńcze - SUO) are provided at the place of residence of the dependent person. Care services are non-cash benefits provided by social assistance services, including assistance with meeting everyday life needs, personal care, nursing recommended by a doctor and, if possible, ensuring contact with the community for elderly persons who require the assistance of other people in this respect and are deprived of it [5].

Care services are one of the important elements of longterm care (LTC). According to the World Health Organization (WHO), long-term care is a system of activities undertaken by informal carers (family, friends, neighbours) and/or professionals (medical, social, other) aimed at providing persons who are not able to independently perform selfservice activities with the highest possible quality of life, consistent with personal preferences and requirements, while maintaining the highest possible level of independence, autonomy, participation and personal dignity [6]. This solution enables the elderly and dependent people to remain and function at home, despite their limitations in meeting basic and necessary needs, and in spite of barriers to integration with the community. It is only the complete inability of the elderly to function even with the help of care services, which is an indication for them to be referred to stationary forms of care, such as social assistance homes or nursing, and treatment facilities.

\section{OBJECTIVE}

The aim of the study was to analyse the costs of providing care services in selected cities in Poland in 2015-2017, and to identify near future needs on this basis.

\section{MATERIALS AND METHOD}

In the research process, data from 12 out of 27 randomlyselected Polish cities with over 120,000 inhabitants (Wrocław, Bydgoszcz, Lublin, Kraków, Opole, Rzeszów, Białystok, Gdańsk, Kielce, Olsztyn, Poznań and Szczecin) was analysed in terms of the form of care services provided, i.e. care services, specialist care services as municipalities' own tasks - financed from the municipal budget and specialist care services for persons with mental disorders - commissioned tasks financed from the State budget. Analysis was also made of the total number of persons covered by assistance, divided into age categories. Data were obtained from Social Assistance Centres in individual cities.

The next stage involved an analysis of the number of hours of care services provided in different forms, the hourly rates and total costs. The research method was data analysis of documentation, followed by drawing up and filling in a Table on this basis.

\section{RESULTS}

Each type of care service, as well as the number of hours and scope of service provided by a social worker, was assessed after conducting a community interview in a person's place of residence. UO (also called a housekeeping service) is a paid benefit, but in special cases (no income, income below the income criterion ${ }^{1}$, difficult financial situation), elderly persons have the possibility of partial or total exemption from payment [5]. If a dependent person has a family, it is reasonable to include family members in the planning of assistance so that the care provided will supplement the family's activities, and allow them to work professionally or have a well-deserved rest. UOs, are the most frequently granted form of assistance, and are most often used by persons over 80 years of age.

SUO is municipalities' optional task, which means that not every municipality has to implement it. This is a special type of service adapted to the type of disease or disability, i.e. care aimed at supporting the treatment process, physical rehabilitation and improvement of impaired body functions. These services are provided by people with specialist qualifications, e.g. nurses, physiotherapists, medical carers or carers of people with disabilities. In Poland, 7 out of the 12 cities surveyed provided SUO. The age categories of recipients were more diverse, which indicated that in addition to the elderly, this form of assistance also included people with disabilities.

Specialist care services for people with mental disorders (SUOP) constitute a separate form of assistance. These services are commissioned by government administration [5]. The rules for granting of these services and payment for them are laid down in the Regulation of the Minister of Social Policy [8], and not municipal regulations, as is the case with other care services. The purpose of this particular form of services is to improve the quality of life of persons with mental disorders by providing them with specialist assistance - in cases where they are deprived of it - by persons with appropriate education and at least six months of work

1. The income criterionwais PLN 701 for a person living alone and PLN 529 for a person living with a family. 


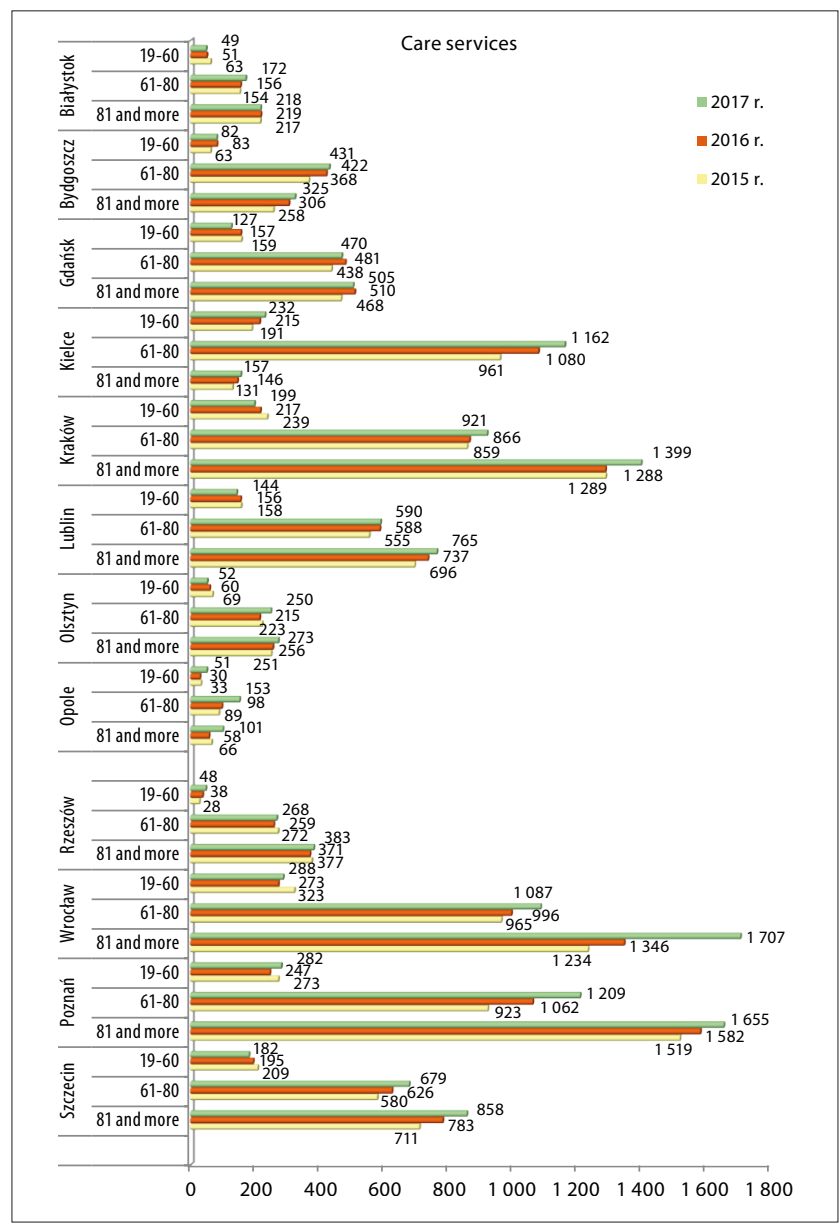

Figure 1. Provision of care services in $2015-2017$ in 12 Polish cities

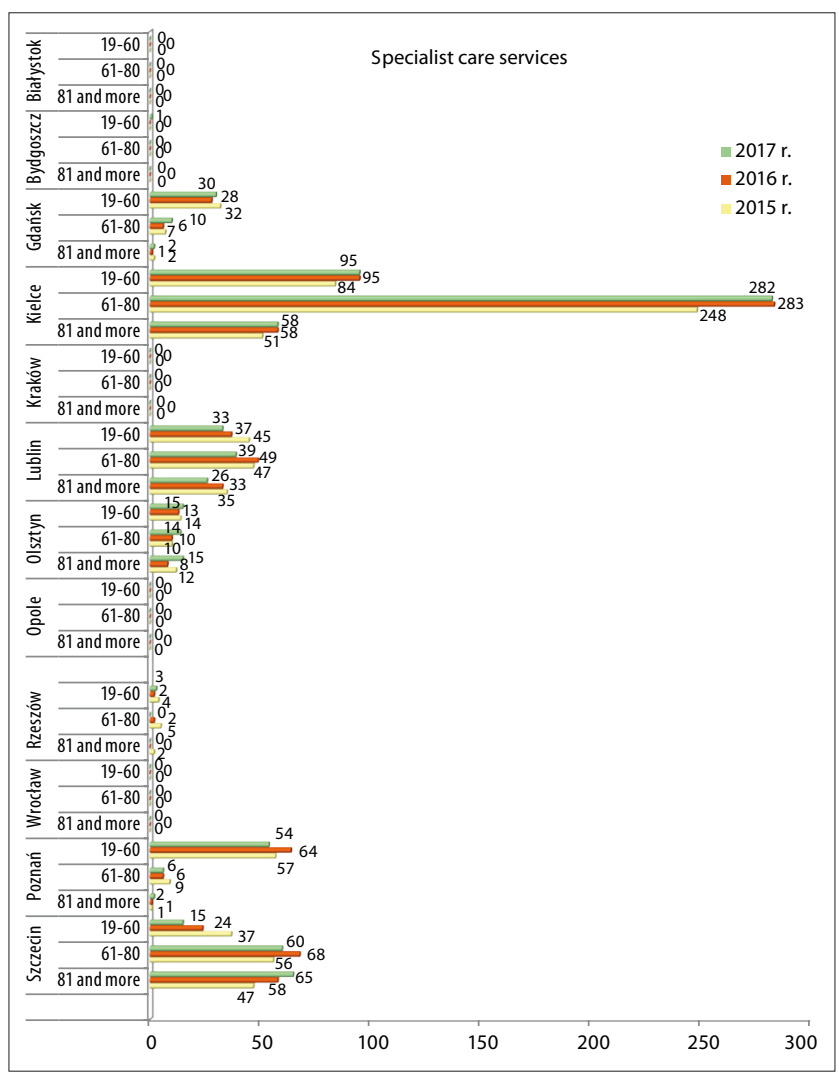

Figure 2. Implementation of specialist care services in 2015-2017 in 12 Polish cities experience in institutions or facilities specializing in the treatment, rehabilitation or education of persons with mental disorders $[5,7]$. The scope of specialist care services for people with mental disorders includes: teaching and developing the skills necessary for independent living, nursing as support of the treatment process, housekeeping assistance and, in exceptional cases, physical rehabilitation and improvement of impaired body functions within the scope not covered by the provisions of the Act on health care services financed from public funds [9]. SUOP are mainly provided to young people.

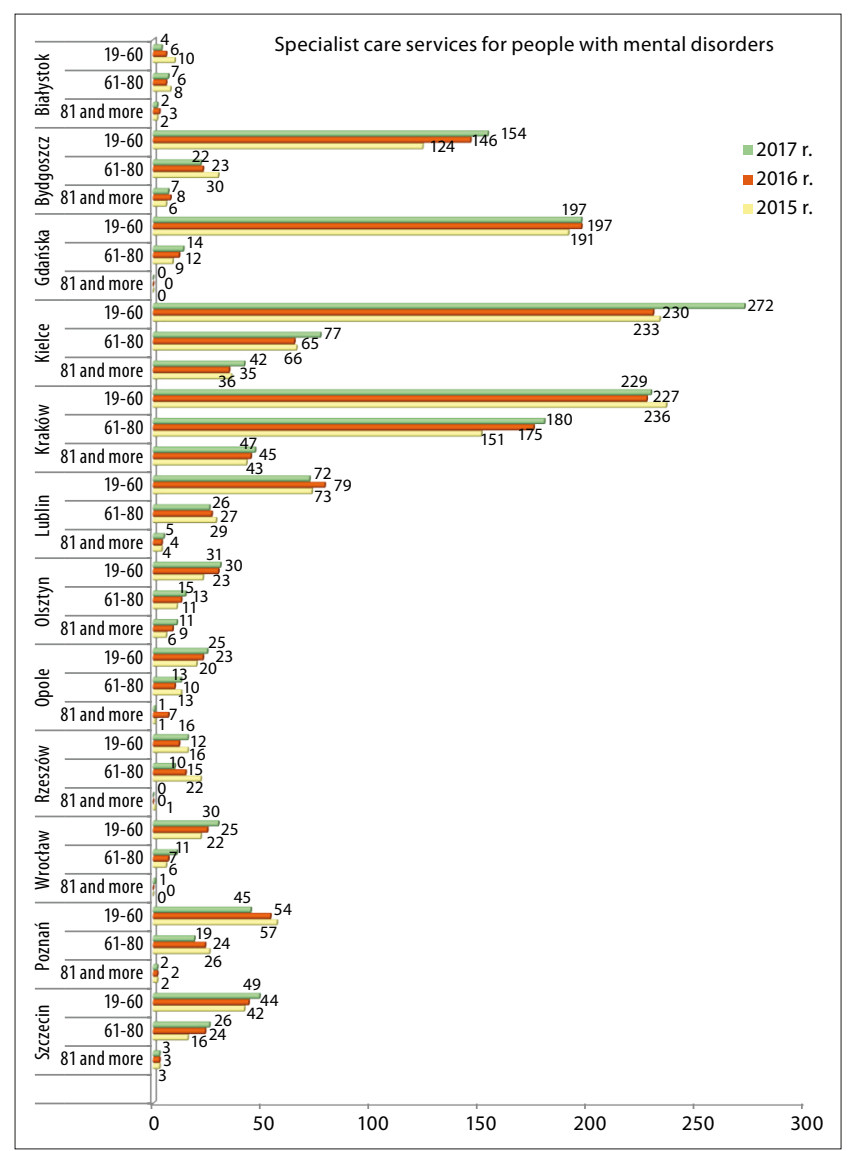

Figure 3. Provision of specialist care services for people with mental disorders in 2015-2017 in 12 Polish cities

All three afore-mentioned forms of care services can be provided by private companies, non-governmental organisations or private citizens, with whom the local social assistance centres have concluded relevant agreements.

In the majority of the cities under study, the cost of care services increased every year, with the largest increase recorded in 2017, which was closely linked to the change in the minimum wage. In 2016, this was PLN 1,850 gross per month under a contract of employment, and an hourly rate of not less than PLN 12 gross [10]. In 2017, it amounted to PLN 2,000 gross under a contract of employment and an hourly rate of PLN 13 gross [11]. The results of the conducted research indicate an increase in the demand for in-home care services in terms of the number of recipients and the number of hours of care granted. The sustained upward trend and the growing unit costs per hour of services provided have significant financial consequences. 
Table 1. Total number of hours and hourly rates of services provided in three forms in selected Polish cities in 2015, 2016, 2017

\begin{tabular}{|c|c|c|c|c|c|c|}
\hline \multirow{2}{*}{\multicolumn{2}{|c|}{$\begin{array}{l}\text { Social Assistance } \\
\text { Centre (OPS) }\end{array}$}} & \multicolumn{2}{|c|}{2015} & \multicolumn{2}{|c|}{2016} & \multirow{2}{*}{$\begin{array}{c}2017 \\
\text { total } \\
\begin{array}{c}\text { number of } \\
\text { hours }\end{array}\end{array}$} \\
\hline & & $\begin{array}{l}\text { total } \\
\text { number of } \\
\text { hours }\end{array}$ & $\begin{array}{c}\text { rate per } \\
\text { hour }\end{array}$ & $\begin{array}{c}\text { total } \\
\text { number of } \\
\text { hours }\end{array}$ & $\begin{array}{c}\text { rate per } \\
\text { hour }\end{array}$ & \\
\hline \multirow{3}{*}{ Bialystok } & UO & 197804,00 & 17,20 & 202919,00 & 17,90 & 214605,00 \\
\hline & SUO & 0,00 & 0,00 & 0,00 & 0,00 & 0,00 \\
\hline & SUOP & 13590,00 & 18,20 & 7949,00 & 19,10 & 7053,00 \\
\hline \multirow{3}{*}{$\begin{array}{l}\text { Byd- } \\
\text { goszcz }\end{array}$} & UO & 122375,00 & 12,00 & 150727,00 & 12,00 & 157435,00 \\
\hline & SUO & 0,00 & 0,00 & 0,00 & 0,00 & 43,00 \\
\hline & SUOP & 53000,00 & 33,60 & 55146,00 & 35,85 & 46255,00 \\
\hline \multirow{3}{*}{ Gdansk } & UO & 336278,00 & 13,89 & 345997,00 & 15,00 & 324452,00 \\
\hline & SUO & 3654,00 & 40,44 & 3387,00 & 39,08 & 4018,00 \\
\hline & SUOP & 37962,00 & 43,73 & 40985,00 & 45,74 & $43,140,00$ \\
\hline \multirow{3}{*}{ Kielce } & UO & 920605,00 & 17,50 & 984024,00 & 18,75 & 1069749,00 \\
\hline & SUO & 56538,00 & 26,00 & 58432,00 & 29,00 & 68272,00 \\
\hline & SUOP & 126495,00 & 25,00 & 139805,00 & 27,50 & 134054,00 \\
\hline \multirow{3}{*}{ Krakow } & UO & 794238,00 & 12,00 & 799495,00 & 18,00 & 818357,50 \\
\hline & SUO & 0,00 & 0,00 & 0,00 & 0,00 & 0,00 \\
\hline & SUOP & 162438,00 & 18,00 & 148246,00 & 19,00 & 131635,00 \\
\hline \multirow{3}{*}{ Lublin } & UO & 701283,00 & 10,00 & 735713,00 & 11,00 & 691001,00 \\
\hline & SUO & 38800,00 & 13,00 & 36306,00 & 14,00 & 31579,00 \\
\hline & SUOP & 41536,00 & 17,00 & 43245,00 & 19,00 & 35398,00 \\
\hline \multirow{3}{*}{ Olsztyn } & UO & 300006,00 & 10,74 & 282683,00 & 13,35 & 276683,00 \\
\hline & SUO & 27873,00 & 13,08 & 28883,00 & 14,40 & 29131,00 \\
\hline & SUOP & 29967,00 & 17,38 & 35532,00 & 18,50 & 33570,00 \\
\hline \multirow{3}{*}{ Opole } & UO & 89322 & 18,50 & 87613 & 18,50 & 103851 \\
\hline & SUO & 00,0 & 00,0 & 00,0 & 00,0 & 00,0 \\
\hline & SUOP & 15568,00 & 20,50 & 19864,00 & 20,50 & 12593,00 \\
\hline \multirow{3}{*}{ Rzeszow } & UO & 318893,00 & 10,00 & 323065,00 & 15,00 & 342549,00 \\
\hline & SUO & 2682,00 & 10,00 & 1549,00 & 15,00 & 1161,00 \\
\hline & SUOP & 14140,00 & 18,00 & 8773,00 & 18,00 & 7547,00 \\
\hline \multirow{3}{*}{ Wroclaw } & UO & 1013181,00 & 11,30 & 1033763,00 & 12,65 & 1144198,00 \\
\hline & SUO & 0,00 & 0,00 & 0,00 & 0,00 & 0,00 \\
\hline & SUOP & 20498,00 & 20,00 & 17658,00 & 29,00 & 19630 \\
\hline \multirow{3}{*}{ Poznan } & UO & 1326658,00 & 11,99 & 1378296,00 & 13,31 & 1290430,00 \\
\hline & SUO & 17365,00 & 19,00 & 16913,00 & 21,32 & 17884,00 \\
\hline & SUOP & 37146,00 & 18,11 & 33696,00 & 18,70 & 28112,00 \\
\hline \multirow{3}{*}{ Szczecin } & UO & 617290,00 & 10,39 & 651334,00 & 13,12 & 726853,00 \\
\hline & SUO & 29537,00 & 16,20 & 44351,00 & 20,15 & 50352,00 \\
\hline & SUOP & 17282,00 & 23,57 & 22994,00 & 32,62 & 27951,00 \\
\hline
\end{tabular}

Source: Social Assistance Centres' material

Table 2. Minimum and maximum rates per hour of services provided in three forms in selected Polish cities in 2015, 2016, 2017

\begin{tabular}{|c|c|c|c|c|c|}
\hline \multirow{2}{*}{$\begin{array}{l}\text { Type of } \\
\text { service }\end{array}$} & \multicolumn{2}{|c|}{ UO } & \multicolumn{2}{|c|}{ SUO } & \multirow{2}{*}{$\frac{\text { SUOP }}{\text { Min }}$} \\
\hline & Min & Max & Min & Max & \\
\hline \multirow{2}{*}{2015} & 10,00 & 18,50 & 13,00 & 40,44 & 17,00 \\
\hline & Rzeszow & Opole & Lublin & Gdansk & Lublin \\
\hline \multirow{2}{*}{2016} & 11,00 & 18,75 & 14,00 & 39,08 & 18,00 \\
\hline & Lublin & Kielce & Lublin & Gdansk & Rzeszow \\
\hline \multirow{2}{*}{2017} & 15,04 & 24,33 & 17,00 & 50,00 & 19,00 \\
\hline & Szczecin & Opole & Rzeszow & Bydgoszcz & Lublin \\
\hline
\end{tabular}

Source: Social Assistance Centres' material

\section{DISCUSSION}

Although the data presented in this study refer to the cost of care in the form of care services provided in selected Polish cities, they show a general trend related to the increase not only in the scope of the necessary number of hours of services provided, but also in the demand for funds. Based on demographic forecasts, a similar situation occurs among seniors living in rural areas, albeit to a slightly smaller extent.

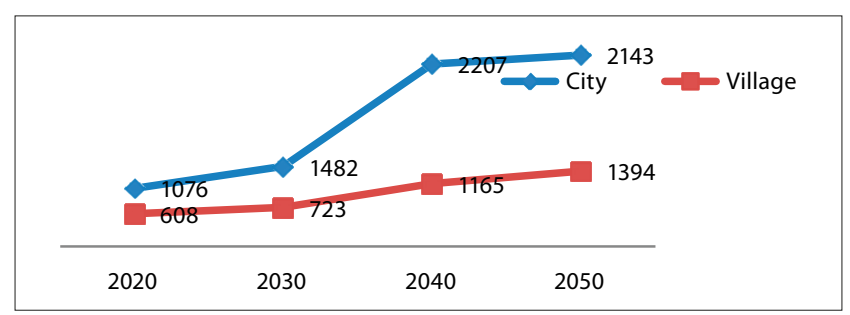

Figure 4. Forecast number of people in Poland aged 80 and over. Source: Central Statistical Office of Poland forecast for 2020-2050

Nationwide reports by the Ministry of Family, Labour and Social Policy (MRPiPS) show that in 2015 [12], 93,272 persons benefited from UO and SUO, and their cost amounted to PLN 423 million. In 2016 [13], the number of care services dropped to 78,847 persons, while their cost increased to PLN 433 million. In 2017 [14], the number of recipients of care services increased to 105,745 people, and the municipal budget funds increased to PLN 562 million. The increase in funding by PLN 129 million and in the number of beneficiaries of services by 26,898 persons from 2016 to 2017 shows the growing demand for in-home care on a national scale, and the need to involve increasing funds from municipal budgets. Research conducted by the OECD in 19 countries (including Poland) shows that total expenditure on long-term care, including care services, ranges between $0.2 \%-3 \%$ of the GDP. The highest costs associated with caring for dependent persons, amounting to well above $2 \%$ of the GDP, are borne by the Scandinavian countries, mainly Sweden (2.89\% of GDP) and Norway (2.15\% of GDP). Germany, the United Kingdom, Australia, Canada and the United States are at a similar level, despite different ways of financing senior care. Spain and Ireland allocate a similar percentage of the GDP for this purpose, despite the fact that in Spain the percentage of elderly persons is over $40 \%$ higher than in Ireland. Poland, with $0.38 \%$ of the GDP, belongs to the group of countries with the lowest expenditure on long-term care [15].

Although the number of persons using care services is steadily growing in Poland, only around $1 \%$ of people over 60 years of age are covered by this form of assistance. A report by the Supreme Audit Office (NIK) shows that nearly $20 \%$ of municipalities in Poland fail to provide support for the elderly in the form of care services, despite the fact that they are obligated to do so. A synthesis of the results of the nationwide NIK audit also shows that care services are most often granted at the request of an elderly person or their representative, and very rarely ex officio - which is permitted by the Act on social assistance [16]. This means that some people in need of support in their place of residence are deprived of it because they are unable to submit an application, and there is no one to do it on their behalf, or they have no knowledge about the existence of this form of assistance. It should be noted that elderly persons requiring support are primarily covered by 
in-home care services, and only when this form of support is insufficient are they entitled to be placed in a social assistance home. Local governments should therefore make use of care services for two reasons:

- Economic - they are a more cost-effective form of assistance than social assistance homes;

- Psychosocial - the elderly should remain in their own homes for as long as possible.

Another important element of care services provision is the standardization of this task. The standard of in-home care services for the elderly [17], developed by a team of experts, has not been implemented on the national level. The fact that local governments can use this tool on a voluntary basis results in a lack of uniformity in the implementation of the task, mainly in terms of the inability to conduct the actual assessment of the quality of care services provided.

The costs of care services provision for dependent persons depend not only on the financing method or the size of the elderly population, to a large extent they are dependent on the organization of formal and informal care. The greater the involvement of informal carers in a particular country, the lower the expenditure on care services for dependent persons, which relieves mainly the local government budgets [15]. Therefore, families play an essential role in the care of elderly persons, and should be important partners in the planning of in-home care services.

The progressing ageing process, which is observed globally, predicts a significant increase in public expenditure related to the provision of social and medical services to the elderly. Therefore, senior policies in different regions of the world indicate similar priorities [18]:

1) development and support of community care in order to ensure that the elderly can stay in their own homes for as long as possible;

2) limiting the role of the State as a provider of care services, and promoting commercial, non-governmental and informal carers [19].

Only mutual complementation of family (informal) carers and professional (formal) carers makes it possible to provide the elderly with complete in-home care services, and postpone their placement in social assistance homes.

\section{CONCLUSIONS}

1) Care services are the fundamental and most cost-effective form of care for elderly persons in their place of residence. Despite this, a growing demand for these services makes it necessary to increase the annual budgets of Polish municipalities for this task.

2) Failure to introduce nationwide standards of care services provision makes it impossible to specify a detailed array of activities to be performed as part of carers' work in elderly persons' place of residence.
3) The increase in the minimum wage has a significant effect on the costs of services provided, but the hourly settlement of the services hinders assessment of their quality.

4) Attention to the educational potential of families involved in care provision for the elderly leads to a fuller and more reliable commitment by family members.

5) The greater the involvement of informal carers in care provision for dependent persons, the lower the costs for local governments.

\section{REFERENCES}

1. Steuden S. Psychologia starzenia się i starości, Wydawnictwo naukowe PWN, Warszawa, 2012.

2. Prognoza ludności na lata 2014-2050, GUS, Warszawa 2014 [access: 20.02.2019]

3. Błędowski P. Potrzeby opiekuńcze osób starszych. In: Aspekty medyczne, psychologiczne, socjologiczne i ekonomiczne starzenia się Lidzi w Polsce, edited by M. Mossakowska, A. Więcek, P. Błędowski, Wyd. Termedia, Poznan 2012; 449.

4. Giezek M, Iwański R. Mieszkania chronione i wspomagane dla osób starszych w ujęciu społeczno-ekonomicznym. Handel Wewnętrzny 2017; 4(369): 287-296.

5. Act of 12 March 2004 on social assistance, consolidated text (Journal of Laws of 2009, No. 175, item 1362, as amended)

6. Fathej M. Cultural change in long-term care facilities: changing facility or changing the system. In: Weiner AS, Ronch JL (red.). Cultural change in long-term care. Haworth Press, New York 2002.

7. Pieńkosz J, Matejczuk A. Funkcjonowanie instytucji opieki w Polsce - Raport podsumowujący wyniki badań terenowych, Warszawa 2015, SRZL.

8. Regulation of the Minister of Social Policy of 22 September 2005 on specialist care services (Journal of Laws of 2005, No. 189, item 1598, as amended)

9. The Act of 27 August 2004 on health care services financed from public funds (Journal of Laws 2004 No. 210, item 2135, as amended)

10. Regulation of the Council of Ministers of September 11, 2015 on the amount of the minimum wage in 2016 (Journal of Laws of 2015, item 1385).

11. Regulation of the Council of Ministers of 9 September 2016 on the amount of the minimum wage in 2017 (Journal of Laws of 2016 item 1456).

12. Ministry of Family, Labour and Social Policy, Information on the situation of elderly persons in Poland in 2015, Warsaw 2016.

13. Ministry of Family, Labour and Social Policy, Information on the situation of elderly persons in Poland in 2016, Warszawa 2017.

14. Ministry of Family, Labour and Social Policy, Information on the situation of elderly persons in Poland in 2017, Warszawa 2018.

15.Long-term care for older people. The OECD Health Project. OECD Publishing, Paris 2005.

16. Supreme Audit Office, https://www.nik.gov.pl/kontrol... [access: 10.05.2019].

17. Standard usług opiekuńczych dla osób starszych świadczonych w miejscu zamieszkania, Projekt 1.18 „Tworzenie i rozwijanie standardów usług pomocy i integracji społecznej” jest współfinansowany ze środków Unii Europejskiej w ramach Europejskiego Funduszu Społecznego, WRZOS 2011.

18. Theobald H. Social exclusion and care for the elderly - theoretical concept and changing realities in European Welfare States. WZB Report no. SP I 2005-301, Berlin 2005.

19. Kröger T. Comparative research on social care. The state of the art. European Commission, Brussels 2001. 